\title{
Examining the Physicochemical and Microbial Qualities and Mineral Content of Selected Brands of Bottled Water Marketed and Consumed in Asaba, Delta State, Nigeria
}

\section{OWAMAH, HI}

\author{
Department of Civil Engineering, Faculty of Engineering, Delta State University, PMB1, Abraka, Oleh Campus, Delta State, Nigeria \\ Email: owamah.hilary@gmail.com; hiowamah@delsu.edu.ng \\ Tel: +2348035705814
}

\begin{abstract}
The quality of bottled water sold in Asaba, Delta State, Nigeria, was investigated in this study. Six (6) brands of highly consumed bottled water were randomly selected for evaluation of physicochemical parameters, metallic and nonmetallic inorganic constituents, and microbial properties. The study revealed that physicochemical parameters such as $\mathrm{pH}$, TDS and Chloride ranged between 6.63 $\pm 0.03-7.54 \pm 0.02,3.3 \pm 0.8-88.4 \pm 6.1$ and $2.48 \pm 0.6-39.3 \pm 3.6$ respectively, while the metal contents were highly variable amongst the bottled water examined. The study also showed from bacteriological analysis, that $5.2 \%$ of tested samples had Klebsiella sp., Streptococcus faecalis and Pseudomonas aeruginosa. Values for the physicochemical and non-metal inorganic elements were below the prescribed maximum limits of the World Health Organization (WHO) and Standard Organization of Nigeria (SON). Generally, the bottled waters were found to be microbiologically safe, going by the results of total coliform and heterotrophic plate count and were also not contaminated by heavy metals. A direct comparison of the values obtained with the mineral water categorization system showed low mineral content and hence most suitable for low-sodium diets. The study recommends regular monitoring and analysis of bottled waters sold and consumed in Nigeria for quality assurance.
\end{abstract}

\section{DOI: https://dx.doi.org/10.4314/jasem.v22i12.19}

Copyright: Copyright () 2018 Owamah. This is an open access article distributed under the Creative Commons Attribution License (CCL), which permits unrestricted use, distribution, and reproduction in any medium, provided the original work is properly cited.

Dates: Received: 30 November 2018; Revised: 22 December 2018; Accepted 31 December 2018

Keywords: Bottled Water, Water Quality, Public Health, Regular Monitoring, Asaba

Though packaged water was not a common place thing about two decades ago, the situation has changed as many people now depend on it (Rahman et al., 2017; Bong et al., 2009). The promotional works of food industries have discouraged people from drinking municipal (tap) water as everyone has been made to believe that bottled waters are safer. Some consumers also believe that bottled water is medicinal (Semerjian, 2011). In recent times, the quality of bottled water has been brought to question especially during storage (Al-Saleh, et al., 2011). Reports about illegal re-filling from unsanitary water sources have also been documented the in literature (Herath, et al., 2012). The Nigerian bottled water enterprise has remarkably grown in the last ten years due to the general perception that borehole water contains contaminants. As obtainable in most developing nations (Rahman et al., 2017), the source of most bottled water in Nigeria is groundwater; which after abstraction, is treated by filtration, boiling, chlorination etc. Although the bottled water industry in Nigeria has grown rapidly, a few reports have shown that the possibility of microbiological contamination exits (Ngwai et al., 2010). There is also, inadequate scientific information in the literature, about the quality of bottled waters consumed in many Nigeria cities like Asaba. The objective of this study was therefore, to analyze the physicochemical and microbial qualities, and mineral content of selected brands of bottled water marketed and consumed in Asaba, Delta State, Nigeria.

\section{MATERIALS AND METHOD}

Sampling: Six (6) common brands of bottled water and four samples of each brand were used for this study. These were obtained from different retail stores within Asaba, for five working days, randomly chosen between the month of April and May, 2017. The sealed bottled waters were refrigerated and analyzed following standard procedures (Clesceri et al., 1998; APHA, 2012).

Testing of water quality: Chemicals of reagent grade were purchased from Onitsha Anambra State, Nigeria for the analysis. For total dissolved solids (TDS), $\mathrm{pH}$ and Electrical conductivity (EC) measurements, HI 98129 combined meter (Hanna Instruments) was utilized. Dissolved oxygen (DO) was determined through the use of a DO Meter (Jenway product, 
Staffordshire, UK). Total hardness (TH), total alkalinity (TA) and chloride were determined using the titrimetric methods (Rahman et al., 2017, APHA, 2012). All the analyses were done in triplicates and mean values computed. Heterotrophs make use of organic compounds for the majority of their carbon needs. With slight modifications, the spread plate method was used to estimate heterotrophic bacteria and total coliforms after slight modifications (Ngwai, 2010, APHA, 2012). Results obtained were reported in $\mathrm{cfu} \mathrm{mL}^{-1}$. The analysis of the metals was done using atomic absorption spectrophotometer (Sens AA 3000, GBC, Australia) in line with the procedures in APHA (2012).

Statistical analysis: Experimental data were statistically analyzed with Microsoft Office Excel 2007 package at a significant level of $\mathrm{p}<0.005$ using the analysis of variance (ANOVA). The standard deviations of values obtained were also calculated to indicate the extent of variations.

\section{RESULTS AND DISCUSSION}

Water-quality parameters: Table 1 shows values obtained for the physical properties of the different sampled bottled water brands sold and consumed in Asaba. Electrical conductivity distribution ranged from 5.70 to $148.40(\mu \mathrm{S} / \mathrm{cm})$ with over half of the samples having EC of less than $100(\mu \mathrm{S} / \mathrm{cm})$ (Table 1$)$. Maximum admissible concentration by the WHO is $1000(\mu \mathrm{S} / \mathrm{cm})$ for drinking water. Also, no significant difference in EC values $(\mathrm{P}<0.05)$ was observed among the brands. EC is not only indicative of ions in water; it also increases with the number of ions (Ritter, 2010). In natural waters, total dissolved solids (TDS) mainly come from $\mathrm{Mg}, \mathrm{Na}, \mathrm{K}, \mathrm{Ca}$, chlorides, carbonates, bicarbonates, sulfate etc. (Ritter, 2010) and varies between less than 30 and $6000 \mathrm{mg} \mathrm{L}^{-1}$ (WHO/UNEP \& GEMS, 1989). The physicochemical behaviour of drinking water could change as a result of intrusion of TDS. It also makes water less palatable (WHO, 2003). Though data linking health effects with the ingestion of TDS are scanty, total mortality had been shown to correlate negatively with the concentration of TDS in drinking water (Rahman et al., 2017). The WHO and SON prescribed limit for TDS is $500 \mathrm{mg} \mathrm{L}^{-1}$ (Table 2). Table 1 showed that the TDS in over $90 \%$ of the tested bottled water samples were below $90 \mathrm{mg} \mathrm{L}^{-1}$. Total hardness (TH) is one of the important physicochemical water quality parameters. Dissolved metallic ions such as $\mathrm{Ca}$ and $\mathrm{Mg}$, from rocks, seepage, and runoff are the major contributors of $\mathrm{TH}$ to natural water WHO, 2003). Some other cations like $\mathrm{Ba}, \mathrm{Fe}$ and $\mathrm{Zn}$ also contribute (WHO, 2003). TH in drinking water has not been so linked to adverse health effects in humans (WHO, 2004). When TH in drinking water is above 75 $\mathrm{mg} \mathrm{L}^{-1}$, it could bring about negative effects on the balance of mineral compositions of water (WHO, 2003). Furthermore, when it exceeds $500 \mathrm{mg} \mathrm{L}^{-1}$, it makes water aesthetically unacceptable (WHO, 2003). $\mathrm{TH}$ of less than $9.87 \mathrm{mg} \mathrm{L}^{-1}$ was obtained in all samples and there was no significant difference among values recorded for the different brands $(\mathrm{p}<0.05)$. The $\mathrm{TH}$ of the selected bottled waters marketed in Asaba was found to be less than the upper regulatory limit of the SON and WHO (Table 2), with average value of below $33 \mathrm{mg} \mathrm{L}^{-1}$ in most of the samples.

Table 1: Concentration of physiochemical and microbial parameters of sampled bottled waters

\begin{tabular}{|c|c|c|c|c|c|c|}
\hline \multirow[b]{2}{*}{ Parameters } & \multicolumn{5}{|c|}{ Brand } & \multirow[b]{2}{*}{$\mathrm{F}$} \\
\hline & A & $\mathrm{B}$ & $\mathrm{C}$ & $\mathrm{D}$ & $E$ & \\
\hline \multicolumn{7}{|l|}{ Physical parameters } \\
\hline Electrical conductivity $\mu \mathrm{S} \mathrm{cm}-1$ & $7.20 \pm 1.8$ & $102 \pm 11.6$ & $\begin{array}{l}30.60 \pm 2 \\
.1\end{array}$ & $28.40 \pm 2.4$ & $36.60 \pm 3.2$ & $138.60 \pm 11.3$ \\
\hline Total dissolved solids $\left(\mathrm{mg} \mathrm{L}^{-1}\right)$ & $3.30 \pm 0.8$ & $65 \pm 2.8$ & $13 \pm 2.1$ & $16.30 \pm 0.11$ & $14.20 \pm 0.14$ & $88.40 \pm 6.1$ \\
\hline $\begin{array}{l}\text { Total Hardness } \\
\left(\mathrm{mg} \mathrm{L}^{-1} \mathrm{CaCO} 3\right)\end{array}$ & $2.70 \pm 0.11$ & $7.70 \pm 0.11$ & $\begin{array}{l}2.60 \pm 0 \\
12\end{array}$ & $2.40 \pm 0.15$ & $1.20 \pm 0.15$ & $62.30 \pm 2.2$ \\
\hline Total Alkalinity (mg L ${ }^{-1} \mathrm{CaCO} 3$ ) & $2.4 \pm 0.3$ & $11.90 \pm 0.3$ & $\begin{array}{l}5.10 \pm 0 . \\
21\end{array}$ & $15.40 \pm 0.27$ & $12.30 \pm 0.21$ & $25 \pm 1.8$ \\
\hline $\begin{array}{l}\text { Inorganic non-metal parameters } \\
\mathrm{pH}\end{array}$ & $7.51 \pm 0.02$ & $7.54 \pm 0.02$ & $\begin{array}{l}6.63 \pm 0 \\
03\end{array}$ & $6.72 \pm 0.05$ & $7.44 \pm 0.07$ & $7.32 \pm 0.04$ \\
\hline Chloride $\left(\mathrm{mg} \mathrm{L}^{-1}\right)$ & $2.53 \pm 0.21$ & $39.30 \pm 3.6$ & $\begin{array}{l}2.48 \pm 0 \\
6\end{array}$ & $2.48 \pm 0.6$ & $8.82 \pm 0.8$ & $28.60 \pm 1.2$ \\
\hline $\begin{array}{l}\text { Microbial Parameter } \\
\text { HPC }\left(\mathrm{cfu} \mathrm{L}^{-1}\right)\end{array}$ & $\mathrm{BD}$ & $\mathrm{BD}$ & $26 \pm 3$ & $\mathrm{BD}$ & $\mathrm{BD}$ & $22 \pm 2.0$ \\
\hline
\end{tabular}

Inorganic non-metal constituents: Though $\mathrm{pH}$ is closely related with other water quality parameters, it has not been properly and directly linked to human health. The WHO permissible range for $\mathrm{pH}$ in drinking water is 6.5-8.5 (WHO, 2007). The bottled water $\mathrm{pHs}$ differed significantly at $\mathrm{p}<0.05$ from the lower and 
upper limits of the WHO. Chlorides are mainly found in natural waters in the forms of sodium, potassium and calcium salts (WHO, 2003). Apart from impairment of metabolism by $\mathrm{NaCl}$ and congestive heart failure, toxicity as a result of ingestion of chloride in humans has not been adequately established (Rahman et al., 2017). Though there are only little or no information on the influence of long term high chloride intake, the general belief is that a healthy person can withstand a large dose of chloride intake if fresh water is correspondingly consumed (Rahman, 2017). Chloride concentration of more than $250 \mathrm{mg} \mathrm{L}^{-1}$ can lead to a detectable taste in water (WHO, 2003). The range of chloride in the sampled bottled water brands is $2.48 \pm 0.6-39.3 \pm 3$.6. This was found to be significantly lower $(\mathrm{p}<0.05)$ than the SON maximum permissible limit (Tables 2).

Table 2 Drinking water quality guidelines

\begin{tabular}{|c|c|c|c|}
\hline $\mathrm{S} / \mathrm{N}$ & Parameter & WHO (2006) & SON (2007) \\
\hline 1 & $\mathrm{pH}$ & $6.5-8.5$ & $6.5-8.5$ \\
\hline 2 & Cadmium & 0.003 & 0.003 \\
\hline 3 & Chloride & - & 250 \\
\hline 4 & Chromium & 0.050 & 0.050 \\
\hline 5 & Copper & 2.00 & 1.00 \\
\hline 6 & Iron & 0.30 & 0.30 \\
\hline 7 & Lead & ND1 & 0.01 \\
\hline 8 & Zinc & - & 3.00 \\
\hline 9 & Nickel & 0.020 & 0.02 \\
\hline 10 & Barium & & \\
\hline 111 & Nitrate & 10 & 50.0 \\
\hline 12 & Nitrite & 1.0 & 0.2 \\
\hline 13 & Sulphate & 500 & 100 \\
\hline 14 & Total coliform & $0 \times 10^{2}$ & 10 \\
\hline 15 & E. coli count & $0 \times 10^{2}$ & - \\
\hline \multirow[t]{2}{*}{16} & Electrical & 1000 & 1000 \\
\hline & Conductivity $\left(\mu \mathrm{S} \mathrm{cm}^{-1}\right)$ & & \\
\hline 17 & Total Suspended Solid & - & - \\
\hline 18 & Total Solid & - & - \\
\hline 19 & Total Dissolved Solid & 500 & 500 \\
\hline 20 & Salinity $(\%)$ & - & - \\
\hline 22 & Turbidity & 1 & 5 \\
\hline 22 & Magnesium & 200 & 0.2 \\
\hline 23 & Calcium & 200 & - \\
\hline 24 & Sodium & 200 & 200 \\
\hline 25 & Potassium & 30 & - \\
\hline 26 & Dissolved Oxygen & 4 & 7.5 \\
\hline 27 & $\mathrm{BOD}_{5}$ & - & 6 \\
\hline 28 & Total Alkalinity ( $\left.\mathrm{mg} \mathrm{L}^{-1} \mathrm{CaCO} 3\right)$ & - & - \\
\hline 29 & Hardness $\left(\left(\mathrm{mg} \mathrm{L}^{-1} \mathrm{CaCO} 3\right)\right.$ & 500 & 150 \\
\hline 30 & Colour [apparent (Hz)] & 15 -apparent $(\mathrm{Hz})$ & 15 (TCU) \\
\hline
\end{tabular}

Microbiological parameters assessment: Assessment of bacterial contamination was done using the HPC and MPN indexing (Aksu \& Vural, 2004). From the HPC count in Table 1, more than $90 \%$ of the samples were found to be free from bacteria even as the remaining others had HPC count of less than $18 \mathrm{cfu}$ $\mathrm{mL}^{-1}$. Le Chevallier et al. (1980) had earlier reported that the HPC count in drinking water ranges from less than 1 to $104 \mathrm{cfu} \mathrm{mL}^{-1}$. It is mainly influenced by $\mathrm{pH}$, temperature, residual chlorine and organic matters. Allen et al. (2004) have shown that an increase in HPC count in drinking water may not mean a significant health risk even as no health-related guideline has been given by regulatory agencies. The US EPA has given a maximum permissible limit of $500 \mathrm{cfu} \mathrm{mL}^{-1}$ for HPC count in drinking water (Rahman et al., 2017). All the sampled brands had HPC value far less than the maximum stipulated limits of the US EPA (Rahman et al., 2017). When total coliform count (TCC) in drinking water is positive, it suggests that the water had been exposed to the external ecosystem (Dahunsi et al. 2014). Mainly, TCC comprises pathogenic enteric bacteria such as E. coli, Salmonella spp., Shigella spp., Vibrio spp. (Barua et al., 2016). A positive TCC value signifies that drinking water is unhygienic (Barua et al., 2016). Results from this study showed that all of the bottled water samples either had a zero coliform count or was below detection limit. This is in line with the requirement of the WHO (Table 3).

Metal constituents: Table 3 shows the concentrations of the metals obtained in this study. Metals mainly get to the human system through drinking water. The 
effect of metal ions on humans could be positive and or negative. While some elements are toxic at trace level, others at low concentrations are essential but toxic in excess (Sojobi, 2016). Calcium (Ca), potassium $(\mathrm{K})$, magnesium $(\mathrm{Mg})$ and sodium $(\mathrm{Na})$ are not only important to humans but are hardly found in drinking water at concentrations that could be harmful. The $\mathrm{Ca}, \mathrm{K}, \mathrm{Mg}$ and $\mathrm{Na}$ contents in the bottled waters were significantly $(\mathrm{p}<0.05)$ less than the WHO and SON prescribed maximum values. The US-EPA classified Aluminum, Copper, Iron, Manganese, Silver and Zinc as nuisance elements in drinking water as they cause taste, color, and odor (Rahman et al., 2017). Sliver, Iron, Manganese and Zinc in the sampled bottled waters marketed in Asaba, were below detection limits. Though Copper has been reported to cause odor and taste in drinking water and also to cause gastrointestinal illness in humans (WHO, 2004), its concentration in the sampled drinking water was significantly lower $(\mathrm{p}<0.05)$ than the health based guideline value of the SON and the WHO. Aluminum values in all sampled brands were significantly ( $\mathrm{p}<$ $0.05)$ less than the limits proposed by the SON and the WHO (Tables 2). High level of aluminum in drinking water could be attributed to the use of aluminum salts as coagulants during water treatment (Rahman et al., 2017). It has been reported that potentially toxic elements like Arsenic, Barium, Cadmium, Chromium, Nickel and Lead, can cause cardiovascular health problems, kidney disorders, and cancer in humans
(Owamah et al., 2013). The bottled water brands surveyed in this study were all found to be are free from these harmful metals (Table 3 ).

\section{Mineral Water Categorization of Sampled Bottled Water Brands}

Often times, bottled waters are labeled 'mineral water', even when they do not necessarily meet with established requirements (Rahman et al., 2017). The classification of water as mineral water involves various physical, chemical, hydrogeological, pharmacological, microbiological parameters specifications etc. (Rahman et al., 2017). Some scales used for the categorization of water as mineral water are the EU and German mineral water classifications. These scales use parameters like extent of mineralization (TDS), level of relevant constituents associated with biochemical functions and percentage salinity (chloride) or hardness $(\mathrm{Ca}, \mathrm{Mg}$ ) (Van der Aa, 2003).

Table 4 shows the categorization of the mineral content of sampled bottled waters using the European Union and German mineral water categorization systems. From Table 4, about $60 \%$ of the sampled bottled waters did not meet with the criteria for classification as mineral water. All the samples also contained sodium below $30 \mathrm{mg} \mathrm{L}^{-1}$ and could therefore be said to be good for low sodium containing diets' (van der Aa, 2003).

\begin{tabular}{|c|c|c|c|c|c|c|}
\hline \multirow[b]{2}{*}{ Parameter } & \multicolumn{6}{|c|}{ Brand } \\
\hline & $\mathrm{A}$ & $\mathrm{B}$ & $\mathrm{C}$ & $\mathrm{D}$ & $\mathrm{E}$ & $\mathrm{F}$ \\
\hline $\mathrm{Ba}$ & $\mathrm{BD}$ & $\mathrm{BD}$ & $1.655 \pm 0.032$ & $\mathrm{BD}$ & $\mathrm{BD}$ & $1.655 \pm 0.032$ \\
\hline $\mathrm{Ca}$ & $0.0026 \pm 0.0001$ & $1.44 \pm 0.0003$ & $0.021 \pm 0.0001$ & $0.321 \pm 0.0002$ & $0.021 \pm 0.0001$ & $0.212 \pm 0.002$ \\
\hline $\mathrm{Cd}$ & $\mathrm{BD}$ & $\mathrm{BD}$ & $0.013 \pm 0.0083$ & $0.016 \pm 0.0044$ & $0.011 \pm 0.0072$ & $0.020 \pm 0.0062$ \\
\hline $\mathrm{Cu}$ & $3.43 \pm 0.24$ & $2.33 \pm 0.35$ & $4.51 \pm 0.18$ & $5.52 \pm 0.20$ & $3.62 \pm 0.16$ & $2.43 \pm 0.20$ \\
\hline K & $0.88 \pm 0.12$ & $250 \pm 10.5$ & $28.9 \pm 1.4$ & $22.6 \pm 0.9$ & $30.7 \pm 1.4$ & $19.9 \pm 1.7$ \\
\hline $\mathrm{Mg}$ & $10.5 \pm 0.35$ & $300 \pm 8$ & $12.7 \pm 0.29$ & $8.2 \pm 0.11$ & $12.7 \pm 0.29$ & $10.8 \pm 0.22$ \\
\hline $\mathrm{Na}$ & $0.31 \pm 0.001$ & $19.3 \pm 0.15$ & $3.1 \pm 0.008$ & $5.3 \pm 0.009$ & $2.8 \pm 0.006$ & $4.8 \pm 0.005$ \\
\hline $\mathrm{Pb}$ & $0.9 \pm 0.01$ & $1.2 \pm 0.01$ & $2.3 \pm 0.01$ & $1.8 \pm 0.01$ & $2.1 \pm 0.03$ & $3.4 \pm 0.01$ \\
\hline
\end{tabular}

Table 4: Mineral water content categorization of the sampled bottled waters

\begin{tabular}{lllllll}
\hline Brand & \multicolumn{2}{l}{ Categorization Criteria } & & & \\
\hline & mineral content & & 'Salinity & & 'Hardness & \\
\hline A & Value & Category & Value & Category & Value & Category \\
B & 72.6 & Low & 1.55 & Fresh & 0.0011 & Very Soft \\
C & 16.8 & Very Low & 2.68 & Fresh & 0.0362 & Very Soft \\
D & 14.8 & Very low & 3.53 & Fresh & 0.0032 & Very Soft \\
E & 19.2 & Very low & 3.02 & Fresh & 0.0231 & Very Soft \\
F & 15.3 & Very low & 2.82 & Fresh & 0.0048 & Very Soft \\
\hline
\end{tabular}

${ }^{a}$ Very low mineral content: Mineral content $(T D S)<50 \mathrm{mg} \mathrm{L-1;} \mathrm{Low} \mathrm{mineral} \mathrm{content:} \mathrm{TDS} \mathrm{50-500} \mathrm{mg} L^{-1}$; Intermediate mineral content: TDS 500-1500 $\mathrm{mg} \mathrm{L}^{-1}$; High mineral content: TDS > $1500 \mathrm{mg} \mathrm{L}^{-1}$ ( Rahman et al., 2017). ${ }^{b}$ Fresh: Chloride < $5 \mathrm{mg} \mathrm{L}^{-1}$; Slightly saline: chloride $5-30 \mathrm{mg} \mathrm{L}^{-1}$; Saline: chloride 30-150 $\mathrm{mg} \mathrm{L}^{-1}$; More saline: chloride 150-300 mg L-1; Very saline: chloride: $300-1000 \mathrm{mg} \mathrm{L}^{-1}$; Mineral: chloride 1000-10, $000 \mathrm{mg} \mathrm{L}^{-1}$ ( Rahman et al., 2017). ${ }^{c}$ Very soft: Ca +Mg 0-0.5 mEq L ${ }^{-1}$ Soft: Ca + Mg 0.5-1 mEq L-1 Medium hard: Ca + Mg 1-2

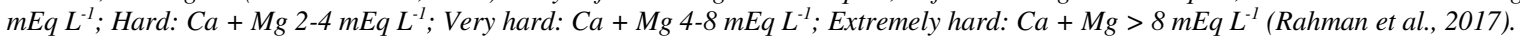

Findings from this study are similar to findings from previous studies. Adekunle et al. (2004) in their study of packaged water consumed in Ibadan, Nigeria, reported that the physicochemical parameters were 
within the WHO prescribed limits except for $\mathrm{pH}$, which ranged from 6.6-9.7. Later study by Ajayi et al. (2008), about the same Ibadan, reported that the physical parameters were within WHO limits for drinking. They further reported that the $\mathrm{pH}$ values ranged from 6.6-9.7 and aluminum (0.00 - $0.34 \mathrm{mg} / 1)$, fluoride $(0.01-1.87 \mathrm{mg} / \mathrm{l})$ and cyanide from $(0.0$ $0.175 \mathrm{mg} / \mathrm{l}$ ) which were not within permissible limits. Ajayi et al. (2008) also reported that bacteriological analysis showed that some of the samples tested had positive coliform counts with the dominant bacteria (Klebsiella sp., $\quad$ Streptococcus faecalis and Pseudomonas aeruginosa). The reports of Dada (2008) for Ekiti State and Igbeneghu and Lamikanra (2014) for Ile-Ife, in Osun State, Nigeria were also similar to the findings of Adekunle et al. (2004) and Ajayi et al. (2008). The present study showed from bacteriological analysis that $5.2 \%$ of the samples tested, had Klebsiella sp., Streptococcus faecalis and Pseudomonas aeruginosa. Cases of gastroenteritis, typhoid and cholera as reported by the Nigerian Federal and State Ministries of Health have been on the increase (Ajayi et al., 2008). This shows that more attention needs to be paid to the quality of water consumed by Nigerians.

Conclusion: The quality of bottled water sold and consumed in Asaba, Delta State Nigeria was investigated in this study. Result obtained showed that the physicochemical and non-metal inorganic elements tested were below the prescribed maximum limits of the World Health Organization (WHO) and Standard Organization of Nigeria (SON). The bottled waters were found to be microbiologically safe and not contaminated by heavy metals. The study also revealed that a few of the samples tested had Klebsiella sp., Streptococcus faecalis and Pseudomonas aeruginosa. Majority of the samples were found to have low mineral content and hence most suitable for low-sodium diets. Regular monitoring and analysis of bottled waters sold and consumed in Nigeria for quality assurance were therefore recommended.

\section{REFERENCES}

Adekunle, LV; Sridhar, MKC; Ajayi, AA; Oluwade, PA; Olawuyi, JF (2004). An Assessment of the health and social economic implications of sachet water in Ibadan Nigeria: a public health challenge. Afr. J. Biomed. Res., 7:5-8.

Ajayi AA.; Sridhar M K C.; Adekunle LV; Oluwande, PA (2008). Quality of Packaged Waters Sold in Ibadan, Nigeria. . Afr. J. Biomed. Res., 11:251258.
Aksu, H; Vural, A (2004). Evaluation of microbiological risks in drinking water. Tesisat, 98, 120-131.

Allen, MJ; Edberg, SC; Reasoner, DJ (2004). Heterotrophic plate count bacteria what is their significance in drinking water? Intern. J. Food Microbio. 92(3): 265-274.

Al-Saleh, I; Shinwari, N; Alsabbaheen, A (2011). Phthalates residues in plastic bottled waters. $J$. Toxicol. Sci., 36(4): 469-478.

APHA (2012). American Public Health Association, AWWA-American Water Works Association, WEF-Water Environment Federation].

Barua, R; Barua, S; Fatema-Tuz-Zohora, M. R; Uddin, M. S; Hasegawa, H; Rahman, IMM (2016). Bacteriological and physicochemical characteristics of Kaptai lake water in terms of public health significance. Intern. J. Sci. Res. Environ. Sci., 4(2): 31-39.

Bong, YS; Ryu, JS; Lee, KS (2009). Characterizing the origins of bottled water on the South Korean market using chemical and isotopic compositions. Analytica Chimica Acta, 631(2): 189-195.

Clesceri, LS; Greenberg, AE; Eaton, AD (1998). Standard methods for the examination of water and wastewater (20th ed.). Washington, D.C: APHA-AWWAWEF.

Dada, AC (2009). Sachet water phenomenon in Nigeria: Assessment of the potential health impacts. Afr. J. Microbiol. Res., 3(1): 015-021.

Herath, AT; Abayasekara, C L; Chandrajith, R; Adikaram, NK B (2012). Temporal variation of microbiological and chemical quality of noncarbonated bottled drinking water sold in Sri Afri. J. Microbiol. Res., 3 (1): 015-021.

LeChevallier, MW; Seidler, RJ; Evans, T (1980). Enumeration and characterization of standard plate count bacteria in chlorinated and raw water supplies. Appl. Environ. Microbiol, 40(5): 92230.

Rahman, IMM; Barua, S, Barua, R; Mutsuddi, R; Alamgir, M; Islam, F; Zinnat, A; Begum, H; (2017). Quality assessment of the non-carbonated bottled drinking water marketed in Bangladesh and comparison with tap water. Food Contr.73: 1149-1158. 
Ngwai1, YB; Sounyo, AA; Fiabema, SM; Agadah, GA; Ibeakuzie, OT (2010). Bacteriological safety of plastic-bagged sachet drinking water sold in Amassoma, Nigeria. Asian Pacific J. Trop. Med., 555-559.

Ritter, JA (2010). Water quality. Denver, CO: American Water Works Association.

Semerjian, L A (2011). Quality assessment of various bottled waters marketed in Lebanon. Environ. Monit. Asses. 172(1-4), 275-285.

Van der Aa, M (2003). Classification of mineral water types and comparison with drinking water standards. Environ. Geol., 44(5): 554-563.

WHO (2003). Chloride in drinking-water e Background document for development of WHO guidelines for drinking-water quality (WHO/SDE/WSH/03.04/03). Geneva: World Health Organization.

WHO (2004). Copper in drinking-water e Background document for development of WHO guidelines for drinking-water quality (WHO/SDE/WSH/03.04/88). Geneva: World Health Organization.

WHO (2007). pH in drinking-water- Revised background document for development of WHO guidelines for drinking-water quality (WHO/SDE/WSH/07.01/1). Geneva: World Health Organization.

WHO/UNEP, \& GEMS (1989). Global freshwater quality. Oxford: Alden Press. Zoeteman. 